\title{
Article \\ Techno Economic Assessment of Hybrid Renewable Energy Systems Based on Power to Hydrogen and Methane Gas Concepts
}

\author{
Ahmed Boubenia ${ }^{1,2}$, Ahmed Hafaifa ${ }^{2 *}$, Abdellah Kouzou ${ }^{2}$ and Mohamed Becherif ${ }^{3}$ \\ 1 MESOnexTeam/URMPE, M. Bougara University, Boumerdès 35000 Algeria; Email: \\ boubeniaa@univ-boumerdes.dz \\ 2 Applied Automation and Industrial Diagnostic Laboratory, University of Djelfa 17000 Algeria; Emails: \\ hafaifa.ahmed.dz@ieee.org, kouzouabdellah@ieee.org \\ 3 FEMTO-ST UMR CNRS 6174, FCLab FR CNRS 3539, UTBM, 90010 Belfort (cedex), France; Email: \\ mohamed.becherif@utbm.fr \\ * Correspondence: hafaifa.ahmed.dz@ieee.org; Tel.: +213555233674
}

\begin{abstract}
This paper deals with the techno-economic study of the hybrid renewable energy system based on energy storage aspect under the form of hydrogen and methane. Indeed, with the intermittency of the renewable energy sources such as photovoltaic and wind energy, several problems of produced energy injection to the power system network can be encountered due to the shortage or the excess of these sources. This situation appeals the use of systems that ensure the stability of network based on the storage of energy surplus into gas using electrolyzer systems, which will be used afterward to cover the eventual shortage. In the present paper, the study of performance of each pathway of methane and hydrogen storage has been performed by the treatment of multiple scenarios via different architecture case studies in an Algerian location. Whereas, the energy produced by the photovoltaic system, the wind energy and the gas micro turbine sources are considered similar in each case. The modeling and simulation of the studied system operation under optimization criteria has been performed in this work, where the main aim is to define the appropriate configuration taking into account the different with low costs of investment, maintenance operation and immediate reactivity with a big storage capacity.
\end{abstract}

Keywords: Hybrid renewable energy; Electrolyze; Hydrogen; Methane; Power to Gas Concept.

\section{Nomenclature}

HRE Hybrid renewable energy

RE Renewable energy

PV Photovoltaic

WE Wind energy

MGT Micro Gas turbine

RES Renewable energy systems

PVS Photovoltaic Systems

WECS Wind Energy Conversion Systems

CAESS Compressed air energy storage system

PHESS Pumped hydro energy storage system

FESS Flywheel energy storage system

BESS Battery energy storage system
SNG Synthetic Natural Gas

$\mathrm{H}_{2}$ Hydrogen

$\mathrm{CH}_{4} \quad$ Methane

PtG Power to Gas

HRES Hybrid renewable energy systems

$\mathrm{CO}_{2} \quad$ Carbone dioxide

$\mathrm{PtH} \quad$ Power-to-Hydrogen

PtM Power-to-Methane

$\mathrm{CO}$ Carbon monoxide

CAPEX Capital expenditure

OPEX Operational expenditure $V_{H 2}$ Volume of Hydrogen in Tank

$V_{H 2 \text { min }}$ Minimum Volume of

Hydrogen in Tank 


$$
\begin{array}{ll}
V_{\mathrm{CO} 2} & \text { Volume of Carbon dioxide } \\
V_{\min } & \text { Minimum Volume of } \mathrm{CO} 2
\end{array}
$$

required for methanation

CHP Combined heat power

DG Distributed generation

AEL Alkaline Electrolysis

PEM Polymer Electrolyte

Membranes

DC Direct current

$\mathrm{H}_{2} \mathrm{O} \quad$ Water

$\mathrm{O}_{2}$ Oxygen Standard enthalpy of reaction

$\Delta H_{r}^{o} \quad$ Standard enthalpy of reaction

PEMFC Proton Exchange Membrane Fuel Cells

PAFC Phosphoric Acid Fuel Cells

MCFC Molten Carbonate Fuel Cells

$F_{i} \quad$ Mass flow rate

$i \quad$ Elements

$I \quad$ Electric current

$M_{i} \quad$ Atomic mass of the element $i$

$x_{c} \quad$ Current efficiency

$\vartheta_{i} \quad$ Valence of the element $i$

$U$ Overall voltage

$u$ Cells voltage

$n_{c s}$ Number of cells in series

$E_{\text {rev }}$ Reversible decomposition voltage

$\eta_{A a} \quad$ Activation overvoltage at the anode

$\eta_{A c} \quad$ Activation overvoltage at the cathode

$R I_{\text {electrolys }}$ Electrolysis Voltage

$R I_{\text {diaphragme }}$ Diaphragm Voltage

$E^{0}$ Potential of oxidation-reduction

$R \quad$ Ideal gas constant

$T$ Electrolysis Temperature

$P \quad$ Electrolysis pressure

$a_{\mathrm{H} 2 \mathrm{O}} \quad$ Solution Activity

$F \quad$ Faradays constant $=96500$
$\eta_{A}$ Activation overvoltage

a Coefficient of energy sharing

$j_{0} \quad$ Density of the currents exchanged at the cathode

$j \quad$ Density of the currents

exchanged at the anode

$a_{a c}$ Coefficient of energy sharing at the cathode

$a_{a a} \quad$ Coefficient of energy sharing at the anode

$E_{F C L} \quad$ Fuel cell potential

$E_{\text {Nernst }}$ Thermodynamic potential of a unit cell

$\eta_{\text {act }} \quad$ Activation polarization

$\eta_{\text {ohm }} \quad$ Ohmic polarization

$\eta_{\text {conc }} \quad$ Concentration polarization

$P_{H 2}^{*} \quad$ Hydrogen partial pressures

$P_{O 2}^{*} \quad$ Hydrogen partial pressures

$T$ Absolute operating temperature of the stack $(\mathrm{K})$

$E_{s} \quad$ Voltage of unit cells connected

$n$ Number of connected cells

$\chi_{F C L} \quad$ Efficiency of fuel cell

$F_{H 2} \quad$ Hydrogen mass flow

$P_{F C L} \quad$ Electric power delivered

$V_{F C L} \quad$ Cell output voltage

$L C_{H 2}$ Lower calorific value of hydrogen

$V_{s} \quad$ Volume of the reactor

$w_{0}$ Reaction speed

$S A$ Membranes Nickel Surface

$m_{c o} \quad$ Mass flow of carbon

$\rho_{\mathrm{CO} 2} \quad$ Carbon dioxide density

$\rho_{N i} \quad$ Nickel catalysis density

$k_{1}$ Constant of the used catalyst

$C_{1}$ Constant of the used catalyst

$C_{2}$ Constant of the used catalyst

\section{Introduction}

With the actual growth of the global electrical energy demand and its crucial role in all kinds of domestic, commercial and industrial activities, and due to the to the environmental aspect and the expected depletion of traditional energy sources in the near future, the problem of transition for other sources of energy is more urgent than before to be solved. Indeed, the impact of such transition will necessarily lead to the search for new ways and methods to ensure the transition toward Renewable Energy Systems (RES) that will be more efficient for electrical energy production, use and storage. Indeed, due to the energy sources availability and the technological and economic 
reasons this transition is based mainly on the exploitation of Photovoltaic Systems (PVS) and Wind Energy Conversion Systems (WECS). However, the inherent issue of both of these technologies are depending directly on the volatile and random weather condition which may lead to the presence of fluctuation in the total produced power. Especially when these energy sources are connected to the network power systems, where this fluctuation can have critical effects on the quality of the transferred power [1]. On the other side, advanced operational techniques and improved control strategies will be required to ensure a safe, stable and reliable operation of the electric power system.

The storage systems are one among such options to improved the quality of electric power based on renewable energy sources, where these systems ensure the storage of the excess energy during overproduction or under consumption periods [2]. For this purpose, several indirect electrical energy storage systems have been used such as compressed air energy storage system (CAESS), pumped hydro energy storage system (PHESS), flywheel energy storage system (FESS) , battery energy storage system (BESS), hydrogen and Methane or Synthetic Natural Gas (SNG) [3]. In this work the storage of energy via the production of Hydrogen $\left(\mathrm{H}_{2}\right)$ and Methane $\left(\mathrm{CH}_{4}\right)$ is investigated, these systems are known as the Power to Gas (PtG) storage systems, they are actually attracting more attention of energy actors, industries and researchers, where these systems are the keystone in hybrid renewable energy systems (HRES). Indeed, in the near future, the increased operation of PtG systems will be considered as an important solution of energy storage, where it is proved in recent researches that the production of $\mathrm{H}_{2}$ and $\mathrm{CH}_{4}$ is the promising key of multiples problems of HRE systems, due to the large scale long term storage and the facility of linking power network to gas grid. This can be achieved by $\mathrm{H}_{2}$ production through water electrolysis that will be stored or injected in natural gas grid on one side or to be used with external Carbone dioxide $\left(\mathrm{CO}_{2}\right)$ for $\mathrm{CH}_{4}$ production on the other side. The resulting Methane can be injected into the existing gas grid or gas storage system and can be easily reutilized by energy conversion systems [4]. Power-to-Hydrogen $(\mathrm{PtH})$ pathway represents the less complex technical solution that is ready in terms of current technological availability to be used in real large scale applications. This pathway implies that the hydrogen obtained through the electrolysis process is injected in the natural gas network. Unfortunately some limitations impose the volume of hydrogen that can be injected in the natural gas network without massive changes in the infrastructure and the end-user applications. Whereas, recent studies report that this limit is situated between 7 and 20 percent of hydrogen concentration [5, 7-9].

However, with a safe value considered to be between 2 and 7 percent Technical limits can also occur given specific end-user appliances, such as gas vehicles, compressors, gas turbines and aquifer storage, that might not tolerate a hydrogen concentration above a certain threshold. Power-to-Methane (PtM) represents the more complex technological pathway of the PtG concept, bringing $\mathrm{CO}_{2}$ into the equation, with the aim of offering an even better storage capacity and flexibility by accessing the natural gas transport and distribution infrastructure without any limitations related to the injected gas concentration, while in the same time emphasizing the environmental advantages of this technology. This pathway is considered a solution of $\mathrm{CO}_{2}$ emissions, it can be used in order to achieve some environmental gains, where one of its most important steps consist of the $\mathrm{CO}_{2}$ capturing from $\mathrm{CO}_{2}$ emitters such as power plants, cement or steel industry, refineries [5]. The advantage of Power to Hydrogen pathway is related to the Hydrogen characteristics, it has a very high specific energy density, that is to say, it contains a lot of energy in a small mass: (Hydrogen: $120 \mathrm{MJ} / \mathrm{kg}$ ). When it is used, it causes only the release of water vapor, avoiding any production of carbonaceous gases such as carbon monoxide ( $\mathrm{CO}$ ) or $\mathrm{CO}_{2}$. However, it must be compressed to high pressures (200 bar to 700 bar) to be transported in a reasonable volume. In addition to security problems that it has, this compression takes a lot of energy. It's also stored in specific tanks with composites reinforced by winding filament (specific carbon fiber, mainly but other materials are tested as basalt fibers) [10]. Compared to PtH pathway 
the PtM pathway adds two additional technological processes, $\mathrm{CO}_{2}$ capture and methanation. These additional stages cause efficiency penalties which lower the overall efficiency of the PtG pathway compared the $\mathrm{PtH}$ pathway, in the same time the methanation reaction is an exothermic reaction which generates heat. This is confirmed by the fact that the $\mathrm{CH}_{4}$ combustion enthalpy is lower than the used hydrogen combustion enthalpy. But resulting Methane SNG is compatible with the natural gas network, which means that it can be stored and transported using the existing infrastructure and without additional modifications to the end user appliances. Its combustion does not increase the $\mathrm{CO}_{2}$ emissions when it is produced from the same amount of $\mathrm{CO}_{2}[5,6,26]$.

In this paper, two different PtG scenarios are investigated based on either $\mathrm{H}_{2}$ and $\mathrm{CH}_{4}$ pathways respectively, this concept was developed by lot of researchers and companies, but the difference in this paper is the development and comparison of two process together which can deal finally to an optimal techno-economic pathway that can be combined with the hybrid renewable energy systems.

\section{Economic evaluation of multiple scenarios of PtG systems}

Actually several research works are focusing mainly on the economic studies of HRES, especially systems with intermittent sources of energies, where the main aim is to define the most appropriate systems to be used following the specified sources constraints, on the other side to motivate researchers to develop new technologies to improve the efficiency of such systems. In this section, an economic evaluation is presented for both systems PtH and PtG. Due to references such as E\&E consult, HESPUL, Solagro «Etude portant sur l'hydrogène et la méthanation comme procédé de valorisation de l'électricité excédentaire» and France Strategy (2015) [10]. The investments costs of Electrolyzer chain is in the order of $750000 € / \mathrm{MW}_{\text {input }}$ and for Methanizer

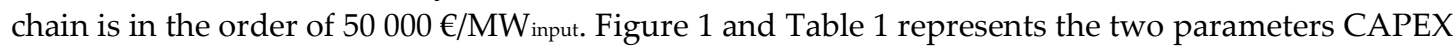
and OPEX of the PtH and PtM chain components during 2014, 2020 and 2030.

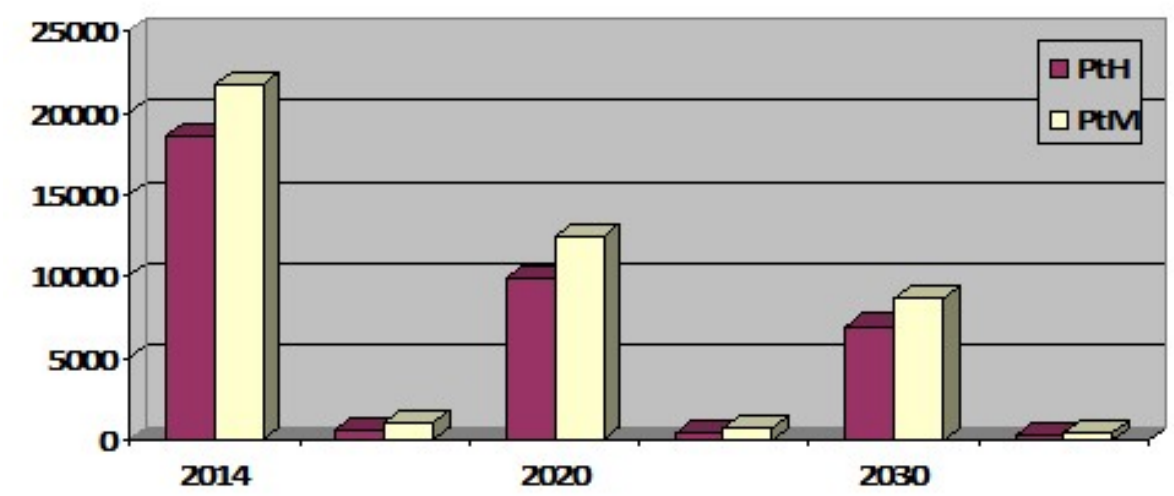

Figure 1. Actual \& previous costs of both process PtH and PtM during 2014, 2020 and 2030

Figure 1 shows the two parameters CAPEX and OPEX of both Power to Gas concepts and their progress in 2014, 2020 and 2030. It can be noted that from 2014 to 2020 an important step of development is known on the field of PEM electrolyzer which affects the costs of both systems. the previsions of 2030 show that the costs of PtM will be more and more decreased, this is due to the concentration of all research on the reduction of $\mathrm{CO}_{2}$ in the atmosphere such as the development of the Methanation reaction and biogas digesters which give more efficiency to this pathway.

Table 1. Costs of the different technologies of PtH \& PtM during 2014,2020 and 2030 (E\&E Consultant, Hespul, Solagro)

\begin{tabular}{llllll}
\hline 2014 & & 2020 & 2030 & \\
\hline CAPEX & OPEX & CAPEX & OPEX & CAPEX & OPEX \\
\hline
\end{tabular}




\begin{tabular}{lllllll}
\hline Unit & $\mathrm{K} €$ & $\mathrm{~K} € / \mathrm{Yr}$ & $\mathrm{K} €$ & $\mathrm{~K} € / \mathrm{Yr}$ & $\mathrm{K} €$ & $\mathrm{~K} € / \mathrm{Yr}$ \\
\hline Electrolyzer & 8500 & 500 & 5575 & 350 & 3920 & 200 \\
\hline Stack Renovation & 5000 & 0 & 0 & 0 & 0 & 0 \\
\hline $\mathrm{H}_{2}$ Compression & 560 & 22,4 & 55 & 10,2 & 33 & 2,3 \\
\hline $\mathrm{H}_{2}$ Storage - Tank & 385 & 6,8 & 226 & 5,8 & 186 & 1,9 \\
\hline $\mathrm{CO}_{2}$ Sources & 109 & 2,6 & 116 & 2,8 & 88 & 2,6 \\
\hline $\mathrm{CO}_{2}$ Compression & 249 & 1,3 & 259 & 2 & 145 & 2,4 \\
\hline $\mathrm{CO}_{2}$ Storage - Tank & 0 & 0 & 0 & 0 & 0 & 0 \\
\hline Methanation Reactor & 2651 & 409 & 2071 & 292 & 1467 & 127 \\
\hline Compression $\mathrm{CH}_{4}$ & 120 & 2,7 & 102 & 2 & 64 & 1,3 \\
\hline Connections & 410 & 8,2 & 410 & 8,2 & 410 & 8,2 \\
\hline Injection station & 700 & 56 & 700 & 56 & 700 & 56 \\
\hline Divers & 5964 & 0 & 5778 & 0 & 3397 & 0 \\
\hline PtH & 18537 & 593,4 & 9855 & 430,2 & 6947,5 & 268,4 \\
\hline PtM & 21666 & 1009 & 12403 & 729 & 8711,5 & 401,7 \\
\hline
\end{tabular}

\section{System under Study}

The system under study in this paper is presented in Figure 2, it consists of permanent energy sources of PV, WE and MGT (independent of the network) and two energy storage systems (Autonomous Hybrid System). The first energy storage system represents the power to Hydrogen (PtH) system, it consists of PEM Electrolyzer, Hydrogen Tanks and PEM fuel cell. The second energy storage systems represents the power to Methane (PtM) system, it consists of PEM Electrolyzer, $\mathrm{CO}_{2}$ source and Methanation reactor [8,3].

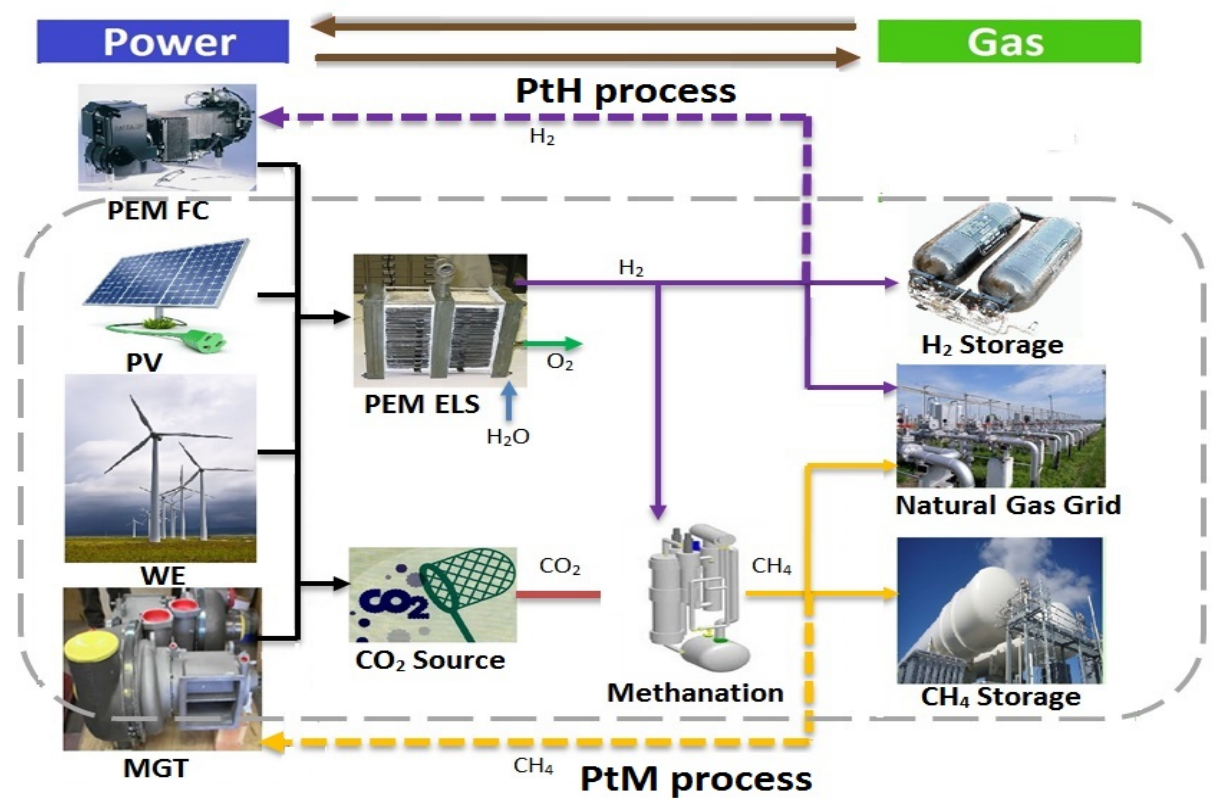

Figure 2. Overall system under-study with two cases of energy storage

\subsection{The proposed management approach flowchart of the studied system}

The flowchart shown in Figure 3, represents the principle of the system under study, the first step is the measurement of the wind speed, the average insolation and the quantity of hydrogen in the tank, this step may be ensured by control cabinet, if the parameter of solar and wind are less than the minimum values and the quantity of hydrogen is more than the minimum, Gas micro turbine 
increases the power production and the fuel cell start production to cover the shortage of energy. On the other hand, the system start measuring and comparing the power production and energy demand (load), if load is less than produced power, the electrolyzer starts producing hydrogen and $\mathrm{CO}_{2}$ capturing, if the quantity of $\mathrm{CO}_{2}$ reaches the required quantity to methanation process, reactor start producing Methane which is used by the MGT, if not the resulting $\mathrm{CO}_{2}$ will stored to reach the required quantity and $H_{2}$ will be stored or used by the Fuel Cell.

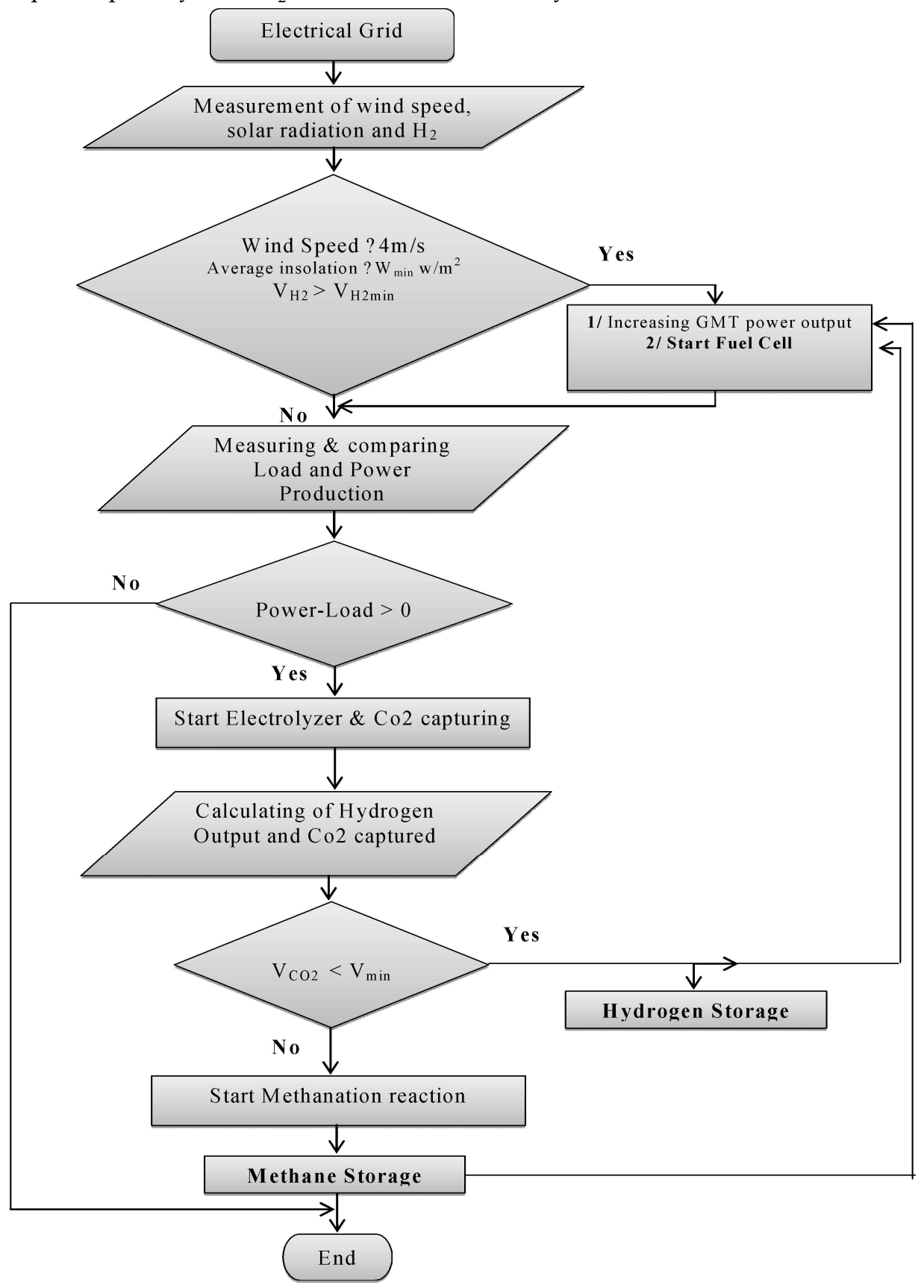

Figure 3. Flowchart of the system under study

\subsection{Permanent autonomous energy sources of the used hybrid system}

The permanent energy sources of the hybrid renewable energy system proposed in this work are based on (WE) and (PV). However, these two sources are constrained on weather conditions such as wind and irradiation availability and temperature [13, 24], Gas Micro Turbine (MGT), shown 
in Figure 4, is used to ensure power supply when (WE) and (PV) power drops, it is widely used as generating unit in distributed generation (DG) systems and as energy producer in combined heat and power generation (CHP) systems. Actually the MGTs are proposed to be used as micro-sources in Micro-grids and autonomous small grids. Indeed, with an electrical power output ranging from $25 \mathrm{~kW}$ to $500 \mathrm{~kW}$, (MGTs) are a relatively new technology that is currently attracting a lot of interest in DG market. During the day the MGT power production is decreased due to the availability of the power produced from the WE and PV of the hybrid system plant [14, 25].

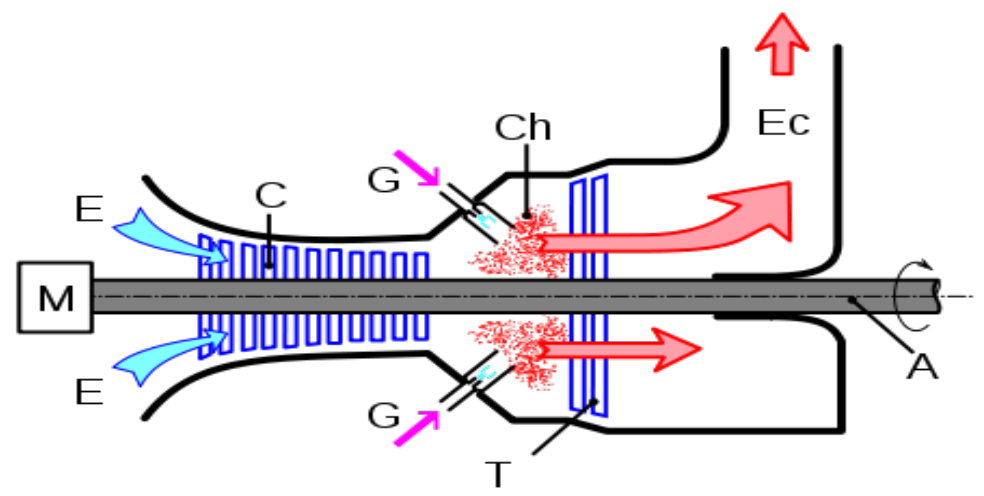

Figure 4. Operating principle diagram of a micro gas turbine

\subsection{Hydrogen pathway}

\subsubsection{PEM Electrolyzer}

Excess of electrical energy can be used to produce hydrogen via water electrolysis. Indeed, there are lots of types of electrolysis technologies that can be used in PtG process such as the Alkaline Electrolysis (AEL), the Polymer Electrolyte Membranes (PEM), and the Solid Oxide Electrolysis (SOEC). Indeed, The SOEC also known as high temperature electrolysis, is the most recently developed electrolysis technology, it is still at the laboratory stage. On the other side, compared to the AEL, the PEM is relatively a new technology where the first commercial PEM electrolyzer was available in the market since in 1978. This technology is based on the use of a solid polymer membranes, where the Oxygen and the hydrogen are produced at the anode and cathode sides respectively as explained in the reaction presented in equations (1-3). The most commonly used membrane material is Nafion [8,10,11]. By applying a DC voltage, oxygen, protons and electrons are produced. At the cathode side, hydrogen is formed by the recombination of electrons and protons overall chemical reaction of the water electrolysis is presented by the following equations [15-16]:

$$
\begin{gathered}
\mathrm{H}_{2} \mathrm{O}(\mathrm{l}) \rightarrow \mathrm{H}_{2}(\mathrm{~g})+\frac{1}{2} \mathrm{O}_{2}(\mathrm{~g}) \quad \text { With }: \Delta H_{r}^{o}=+285.8 \mathrm{kj} / \mathrm{mol} \\
\mathrm{H}_{2} \mathrm{O}+2 e^{-} \rightarrow \mathrm{H}_{2}+\mathrm{O}^{2-} \\
\mathrm{O}^{2-} \rightarrow \frac{1}{2} \mathrm{O}_{2}+2 e^{-}
\end{gathered}
$$




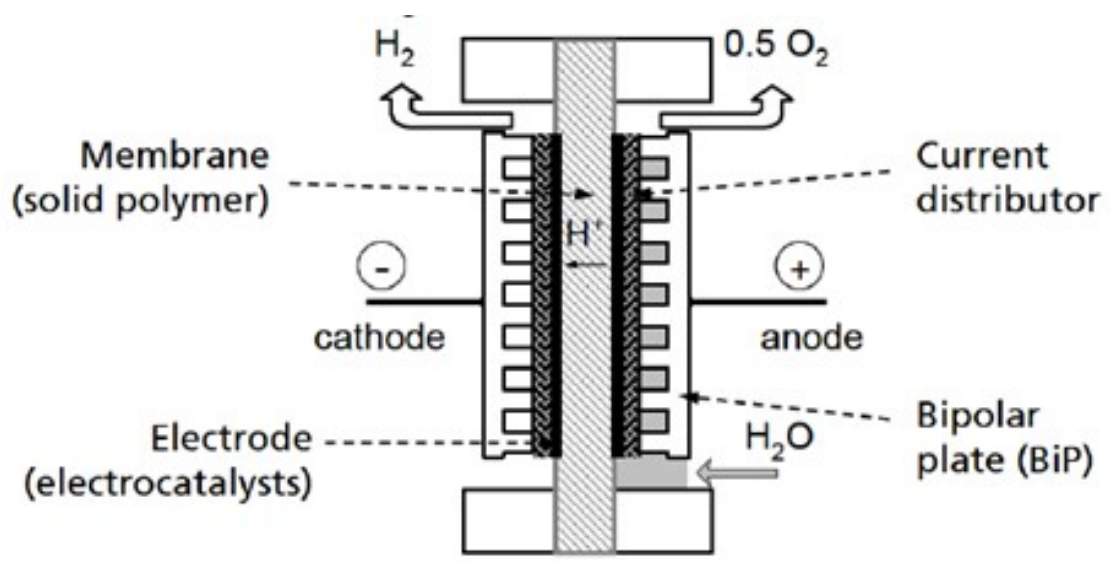

Figure 5. Schematic of PEM electrolysis cell principle

\subsubsection{Hydrogen storage}

The storage of hydrogen is one of the important challenges in PtH pathway, this is due to the fluctuations of power supply of electrolyzer which influences directly on electrolyzer operating time and output hydrogen [16]. Several ways of hydrogen storage have been presented in the literature, they are generally divided into physical storage and material storage. However the hydrogen can be stored as a gas or a as liquid, the storage of hydrogen as a gas typically requires high-pressure tanks (350-700 bar [5,000-10,000 psi]). whereas, its storage as a liquid requires cryogenic temperatures because the boiling point of hydrogen at one atmosphere pressure is $-252.8^{\circ} \mathrm{C}$. Hydrogen can also be stored on the surfaces of solids (by adsorption) or within solids (by absorption) which is known as material storage. [19]. the storage of hydrogen as gas presents more advantages comparing to the others technologies but hydrogen is a small energetic molecule, so it tends to diffuse through any material intended to contain it, this causes embrittlement or weakening of tanks and pipes containing the hydrogen.

\subsubsection{PEM Fuel Cell}

Fuel cells provide a very efficient way of converting the energy in the hydrogen into electricity. They were first made in about 1842 by a Welsh scientist, Sir William Roberare Grove, and were used in spacecraft in the 1960s. Since 1990 there has been intensive development for commercial applications. It consists of two electrodes separated by an electrolyte. The fuel and oxygen are continuously fed into the cell and the products of reaction are withdrawn continuously. When the electrolyte is acidic, the half-cell reactions occurring at the hydrogen electrode (anode) and at the oxygen electrode (cathode) are as follows:

$$
\begin{array}{rlr}
\mathrm{H}_{2} & \rightarrow 2 \mathrm{H}^{+}+2 e^{-} & \text {(Anode) } \\
\frac{1}{2} \mathrm{O}_{2}+2 e^{-}+2 \mathrm{H}^{+} & \rightarrow \mathrm{H}_{2} \mathrm{O} & \text { (Cathode) }
\end{array}
$$

There are quite a few different kinds of fuel cells, with different applications such as Alkaline Fuel Cells, Proton Exchange Membrane Fuel Cells (PEMFC), Phosphoric Acid Fuel Cells (PAFC) and Molten Carbonate Fuel Cells (MCFC) [14-19, 21-23].

\subsection{Methane Pathway}

\subsubsection{Methanation reaction}

Two main process of methanation have been presented in the literature, the biological methanation and the catalytic methanation. In this paper, the catalytic methanation which was developed for the first time on 1902, is investigated due to its practical process in (PtM) pathway. However since the oil crisis on the 1970s, the use of methanation for the production of (SNG) from 
synthesis gas has gained increasing interest and attention, in the same time the $\mathrm{CO}_{2}$ methanation for SNG production has been also investigated for decades [16]. It is important to clarify that to perform the catalytic methanation further processing of the hydrogen and carbon dioxide via the Sabatier reaction is required, shown in Figure 6. In the following, the Sabatier reaction and its implementation process is described, whereas, different $\mathrm{CO}_{2}$ sources including their respective advantages and disadvantages are discussed in next sub-section. The Sabatier process is based on the catalytic hydrogenation of carbon dioxide to methane. The process is operated at temperatures of $250-400{ }^{\circ} \mathrm{C}$ with pressures of $1-80$ bar [1]. A catalyst based on ruthenium which is stable at operation conditions makes the reaction more efficient. It is described by the following reaction:

$$
\mathrm{CO}_{2}+4 \mathrm{H}_{2} \rightarrow \mathrm{CH}_{4}+2 \mathrm{H}_{2} \mathrm{O}
$$

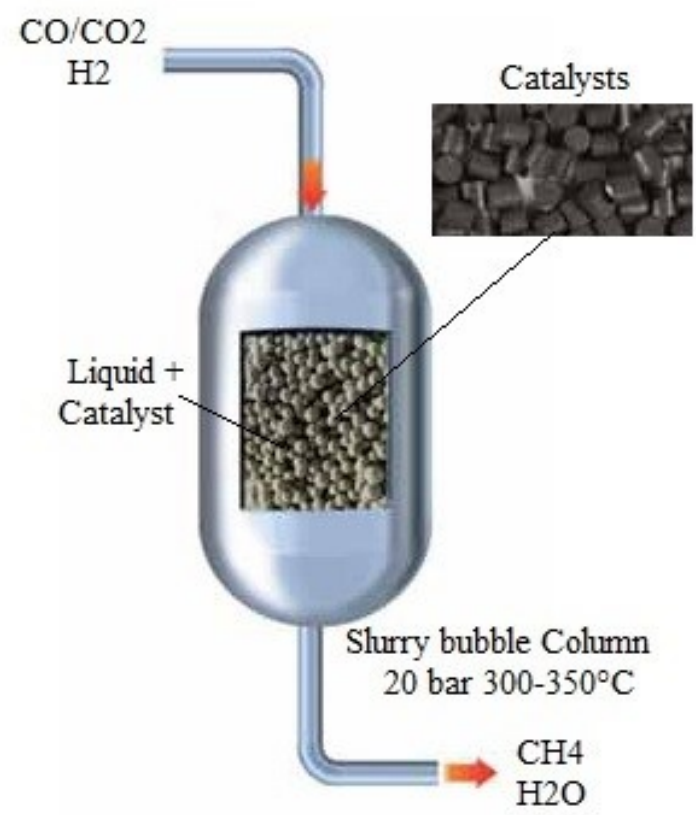

Figure 6. Basic Schematic of Methanation reactor

\subsection{2 $\mathrm{CO}_{2}$ Sources}

The $\mathrm{CO}_{2}$ provided to the PtG process is the $\mathrm{CO}_{2}$ captured from exhausts gases, It is well known that capture of carbon dioxide is one of the major industrial challenges of the coming years. Various experiments are underway to ensure the capture of the greenhouse gas emissions directly to the source, such as the output of thermal power plants, where its concentration in the air is higher than $10 \%$ (by volume) [10, 22]. However, there are various $\mathrm{CO}_{2}$ capture processes such as:

- Oxy-fuel combustion

- Pre-combustion

- Post combustion

The post combustion capture process is the one mostly used process in industry, the goal of this process is to recover $\mathrm{CO}_{2}$ from the boiler flue outlet. The principle is based on the use of two columns: one absorption column for separating the $\mathrm{CO}_{2}$ from other gaseous components using a solvent and a regeneration column for recovering the $\mathrm{CO}_{2}$ in gaseous form and regenerating the solvent at the same time $[10,21,22]$. 


\section{Modeling and simulation}

\subsection{Primary source of energy}

The primary source of energy in this study is represented by WE, PV and MGT, the simulation of these systems is done via Homer Software, sown in Figure 7, where the chosen location is one of optimal sites in Algeria. It is situated in the north of Algeria, at $36^{\circ} 38$ '05 "North $3{ }^{\circ} 35^{\prime} 26^{\prime \prime}$ East, called Tipaza. Climate data is given by Homer Software (NREL sources).

The overall studied HRES is shown in Figure 8 and Table 2, where the input of the renewable energy sources is about $51 \%$. The results of simulation along one year are represented in Figures 9 and 10.

Table 2. Parameters of primary source of energy under Homer

\begin{tabular}{llll}
\hline Production & Size KW & $\mathrm{kWh} / \mathrm{yr}$ & $\%$ \\
\hline PV array & 5 & 8,018 & 5 \\
\hline Wind turbines & 30 & 73,889 & 50 \\
\hline MGT & 25 & 66,612 & 45 \\
\hline Total & 60 & 148,519 & 100 \\
\hline
\end{tabular}
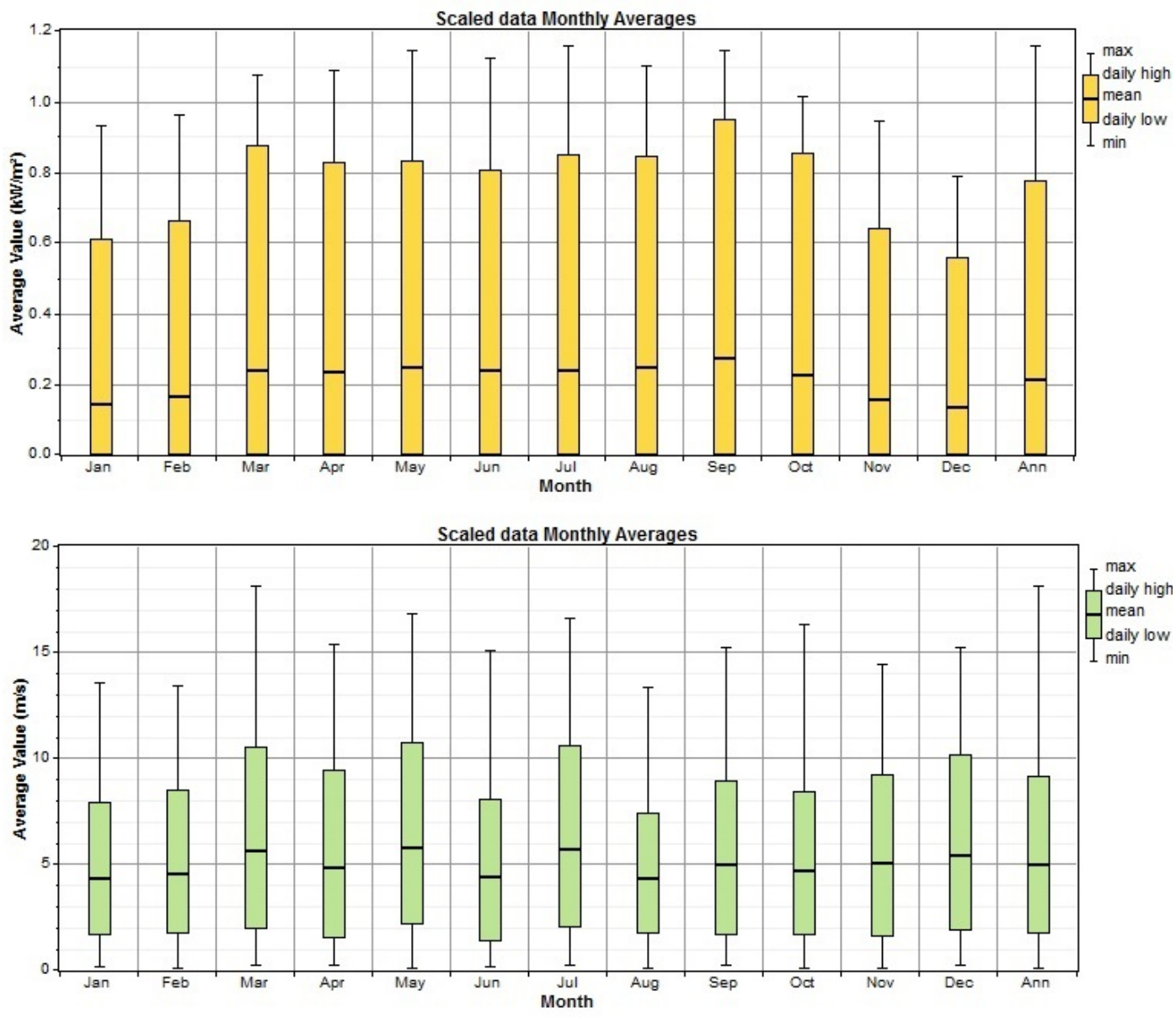

Figure 7. Climate data of the studied site 


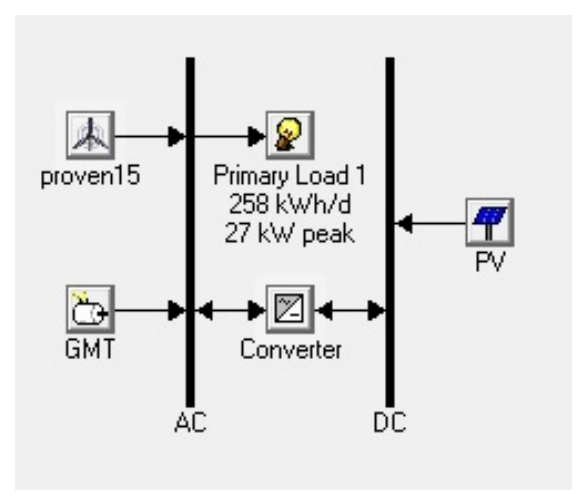

Figure 8. The primary source of energy under Homer

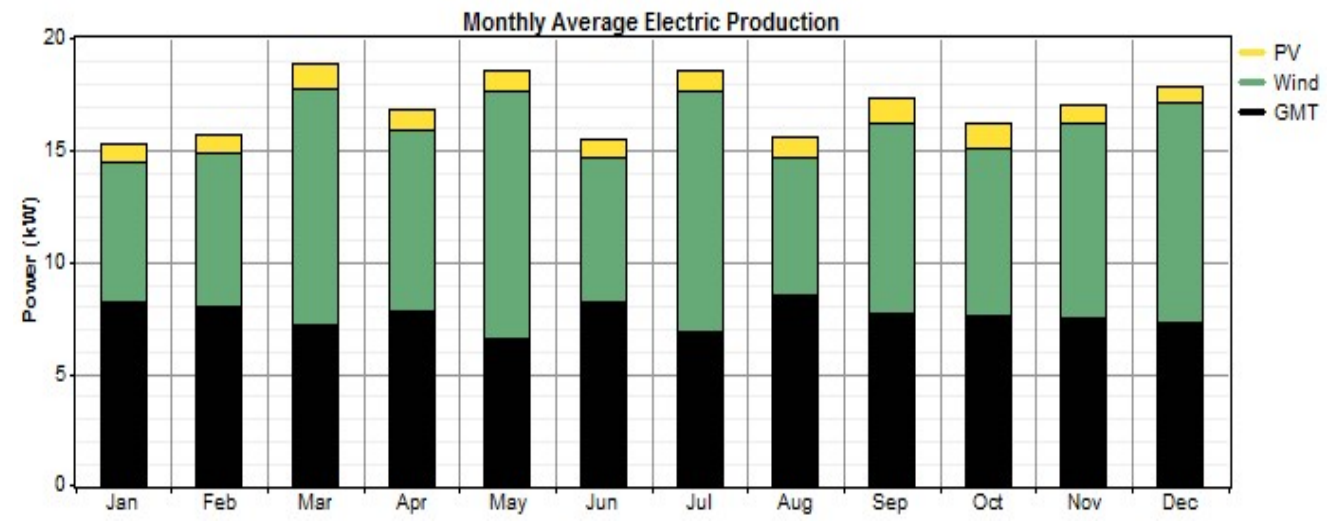

Figure 9. Monthly average of electrical energy production

Figure 8 represents the electrical energy production during one year, where the variation of the primary sources depends directly on wind and solar resources of the studied site, IT can be noted that during the months of March, May and July wind energy participation is the most important in comparison with the PV and the MGT, but during the months of January, February, Jun and August the participation of the MGT is the most important and this is due to the decrease of the onsite wind velocity causing the decrease of wind power production.

Figure 10.A represents the variation of electrical energy consumption and the excess of energy, while Figure 10.B represents the variation of the electrical energy production for the three systems the PV, the WE and the MGT. It is obvious that the increase of the excess of energy has a direct dependence to the WE production and this is due to the daily variation of wind resources.

The MGT plays the role of a support energy source where its intervention is important when the WE production decreases such as during the period between 2end and 3rd January. Contrary to this, it is equal to zero during the days of the 5 th and the 6th January. 

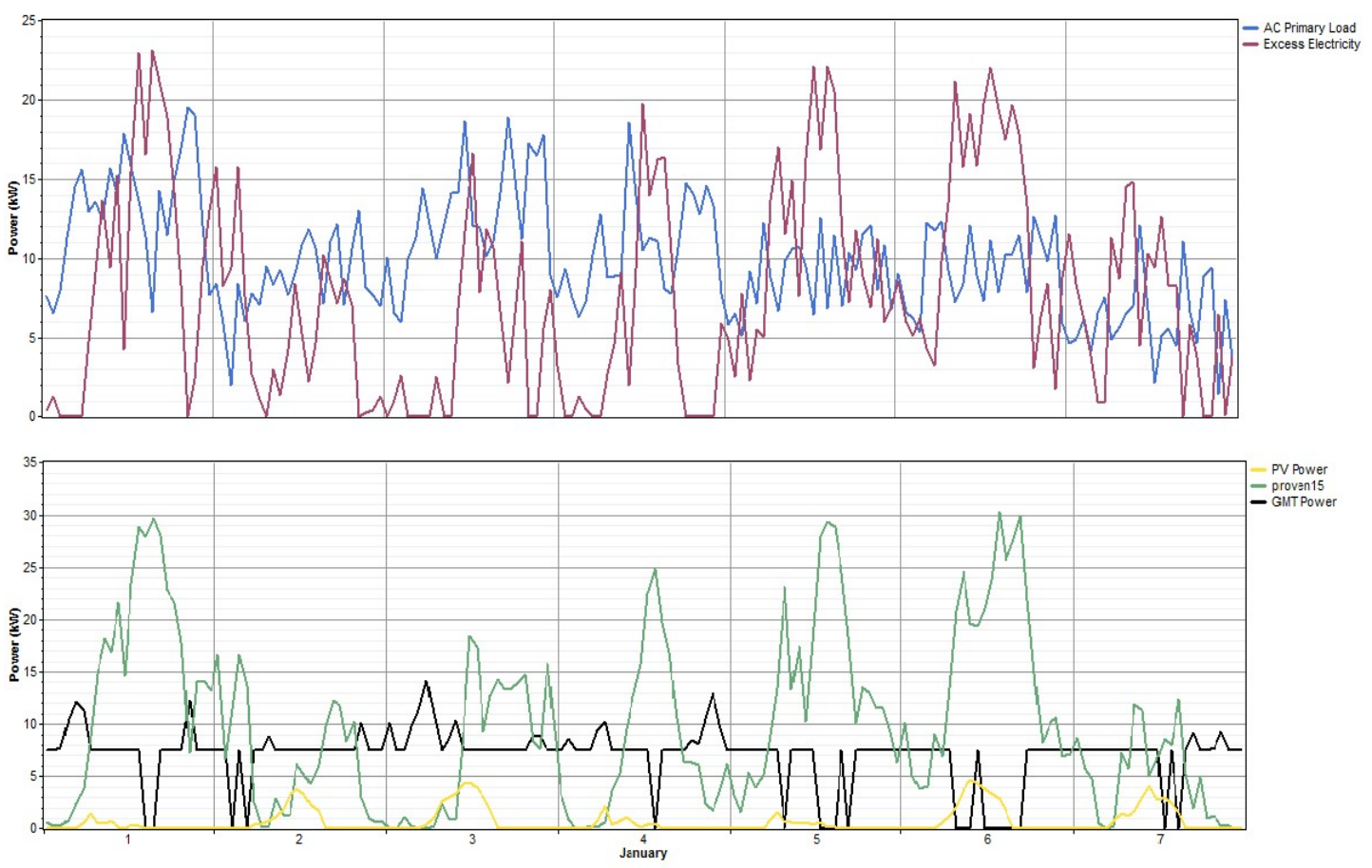

Figure 10. Weekly power production and consumption

The MGT is simulated where the resulting carbon dioxide during one day of energy production is shown in Figure 11.

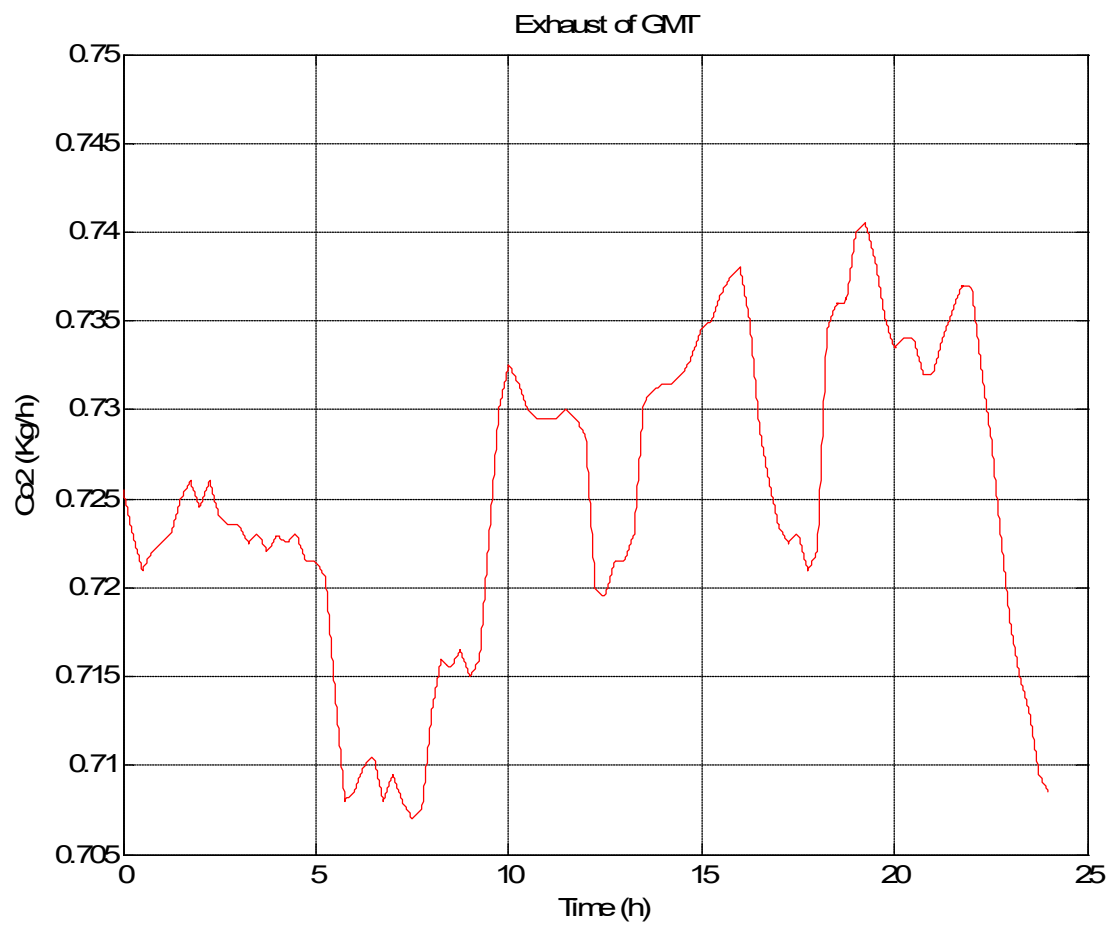

Figure 11. $\mathrm{CO}_{2}$ exhaust of Gas Micro Turbine

Form Figure 11, it can be seen clearly that the value of the resulting carbon dioxide from the MGT during one day of energy production is in the order of $0.72 \mathrm{Kg} / \mathrm{h}$, it starts to decreases from 5 to 
$10 \mathrm{AM}$ and this is due to the production level during the MGT operating time, while it increases to reach about $0.74 \mathrm{Kg} / \mathrm{h}$ on $20 \mathrm{PM}$.

\subsection{PEM Electrolyzer}

The hydrogen production in the electrolyzer is performed via the splitting of water into hydrogen and oxygen which is relatively high because the water molecules have a stable structure at ambient temperature. A potential voltage of $1.23 \mathrm{~V}$ is applied to cells to initiate the electrochemical reactions at the anode and cathode electrodes in the same time [10-18].

Faraday's law expresses the mass flow rate $F_{i}$ of the element $i$ according to the electric current $I$ :

$$
\begin{gathered}
F_{i}=\frac{M_{i}}{\vartheta_{i} F} \cdot x_{c} . I \quad[\mathrm{Kg} / \mathrm{h}] \\
F_{H 2}=0.98 \times \frac{I}{26800}[\mathrm{Kg} / \mathrm{h}]
\end{gathered}
$$

An electrolyzer is constituted by the juxtaposition of electrolysis cells arranged in series. Where $U$ is the overall voltage, it presents the sum of the cells' voltages $(u)$. The voltage of the electrolysis is then expressed:

$$
\begin{array}{r}
U=u \times n_{c s} \\
u=E_{\text {rev }}+\eta_{A a}+\eta_{A c}+R I_{\text {electrolys }}+R I_{\text {diaphragme }}
\end{array}
$$

Where $E_{\text {rev }}$ is the reversible decomposition voltage given by :

$$
E_{\text {rev }}=E^{0}+\frac{3 R T}{4 F} \times \ln (P)-\frac{R T}{2 F} \times \ln \left(a_{H 2 O}\right)
$$

And the activation overvoltage is expresssed:

$$
\eta_{A}=\frac{R T}{2 a F} \times \ln \left(j_{0}\right)-\frac{R T}{2 a F} \times \ln (j)
$$

where $j_{0}, j$ are respectively, the densities of the currents exchanged at the cathode and at the anode.

The input power of electrolyzer in this simulation is the resulting excess power, the parameters of simulation are represented in the appendix.

Figure 12 represents the hydrogen mass flow resulting from electrolyzer, where the variation of the resulting hydrogen is due to operating time of the system. Between 0:00 and 6:00 hydrogen flow reach the maximum mass flow of ( 4 to $5 \mathrm{Kg} / \mathrm{h}$ ) because of the electrical excess which is important in this period due to the lower power consumption such as the period between 16:00 and 18:00, contrariwise in the period between 19:00 to 21:00 the resulting hydrogen is decreased to 1 $\mathrm{kg} / \mathrm{h}$, the same for the period between 10:00 to $16: 00$. 


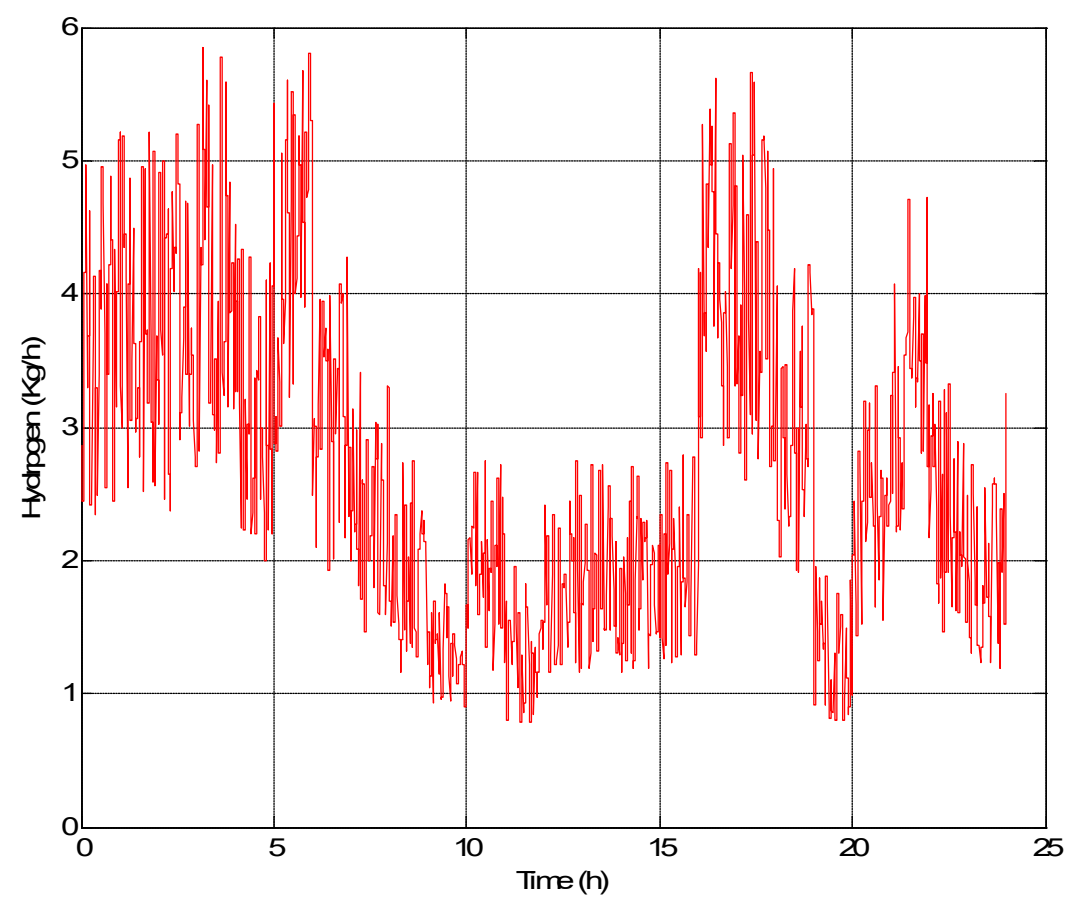

Figur 12. Produced Hydrogen via PEM Electrolyzer

\subsection{PEM Fuel Cell}

The operating principle of the fuel cell is based on the reverse process of the electrolyzer. An oxidation-reduction (in the presence of platinum) reacts hydrogen and oxygen to produce electricity, water and heat according to the equations of the electrochemical reactions occurring at the electrodes of a PEMFC cell, the unit fuel cell voltage is presented [20]:

$$
E_{F C L}=E_{\text {Nernst }}-\eta_{\text {act }}-\eta_{\text {ohm }}-\eta_{\text {conc }}
$$

$\eta_{\text {act }}, \eta_{\text {ohm }}, \eta_{\text {conc }}$ are respectively the activation polarization, the ohmic polarization and the concentration polarization. $E_{\text {Nernst }}$ is the thermodynamic potential of a unit cell. In the case where the liquid water is the product of the PEMFC. The expression of the $E_{\text {Nernst }}$ equation is expressed as follows:

$$
E_{\text {Nernst }}=1.229-0.85 T^{-3} \cdot(T-298.15)+4.3110^{-5} \cdot T \cdot\left[\ln \left(P_{H 2}^{*}\right)+\frac{1}{2} \ln \left(P_{O 2}^{*}\right)\right]
$$

Where $T$ is the absolute operating temperature of the stack $(\mathrm{K}), P_{H 2}^{*}$ and $P_{O 2}^{*}$ are the partial pressures at the interface of hydrogen and oxygen (atm) respectively, in the case of a stack PEMDC producing liquid water. The voltage $\left(E_{s}\right)$ of $(n)$ unit cells connected in series can be calculated as [20]:

$$
E_{s}=n \times E_{F C L}
$$

The energy (thermal) efficiency of the fuel cell (FCL) is defined as follows:

$$
\chi_{F C L}=\frac{P_{F C L}}{F_{H 2} \times L C_{H 2}}
$$


where $P_{F C L}=I \times V_{F C L}, \quad F_{H 2}$ is the hydrogen consumption, $P_{F C L}$ is the electric power delivered, $L C_{H 2}$ is the lower calorific value of hydrogen, $V_{F C L}$ is the cell output voltage for each operating condition and $I$ is the cell load current

For the results, a simplified model of existing Fuel cell in Fuel Cell Laboratory shown in Figure 13, where the electrical power is represented via transfer function according to the datasheet of Nexta model (Fuel cell model: NextaTM 1200 w/ max voltage 50 VDC).

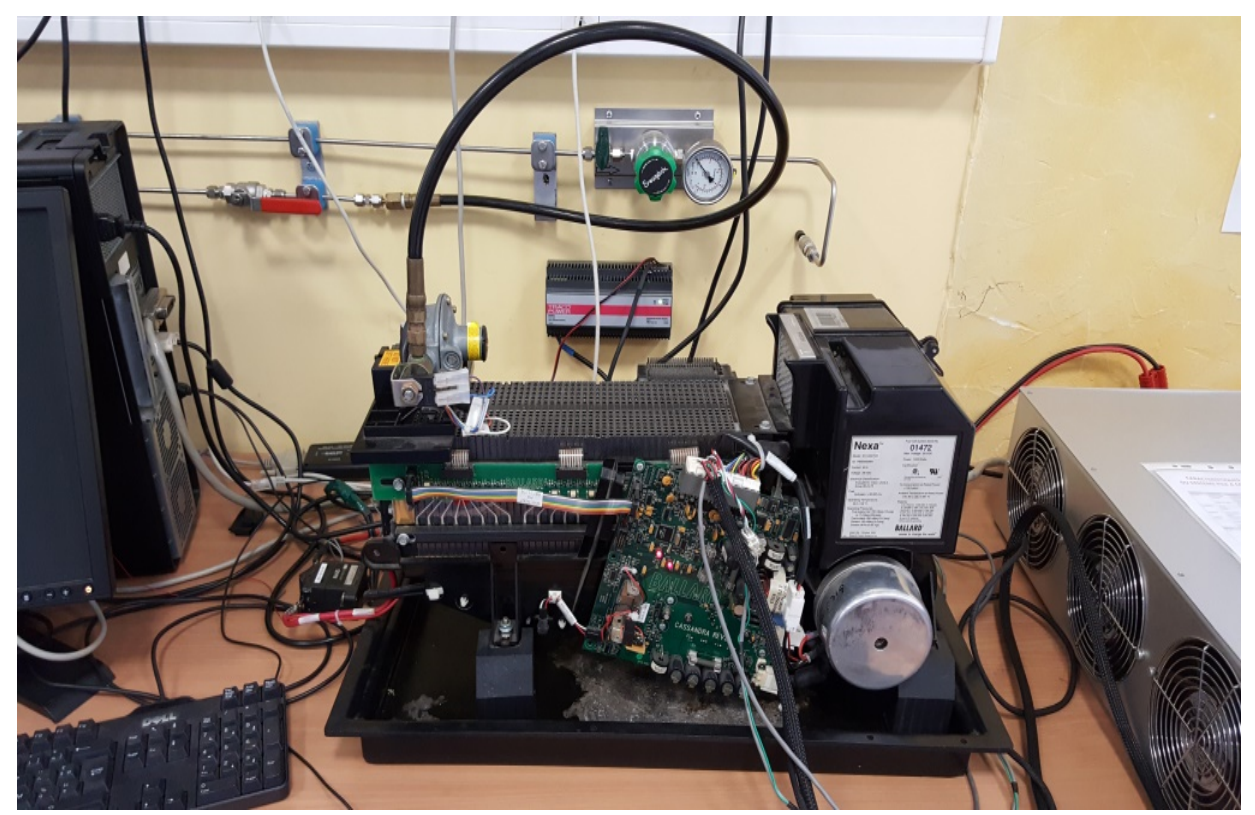

Figure 13. Fuel cell test bench FCLAB/UTBM- Belfort

Figure 14 represents the variation of fuel cell output power according to input hydrogen flow. In this simulation, the temperature and the pressure are not dynamic where output power depends mainly on hydrogen flow. It reaches the maximum of $1.5 \mathrm{Kw}$ when hydrogen input reaches 2.5 to 3.5 $\mathrm{Kg} / \mathrm{h}$ in the period from 00:00 to 7:00 and from 16:00 to 19:00 it reaches 0.5 $\mathrm{Kw}$ due to the decreasing hydrogen flow. Using large quantity of hydrogen tank can manage the output hydrogen which stabilizes the fuel cell output power, in the same time the use of multiple unities of Fuel cell can increase the output power supplied to the grid. 


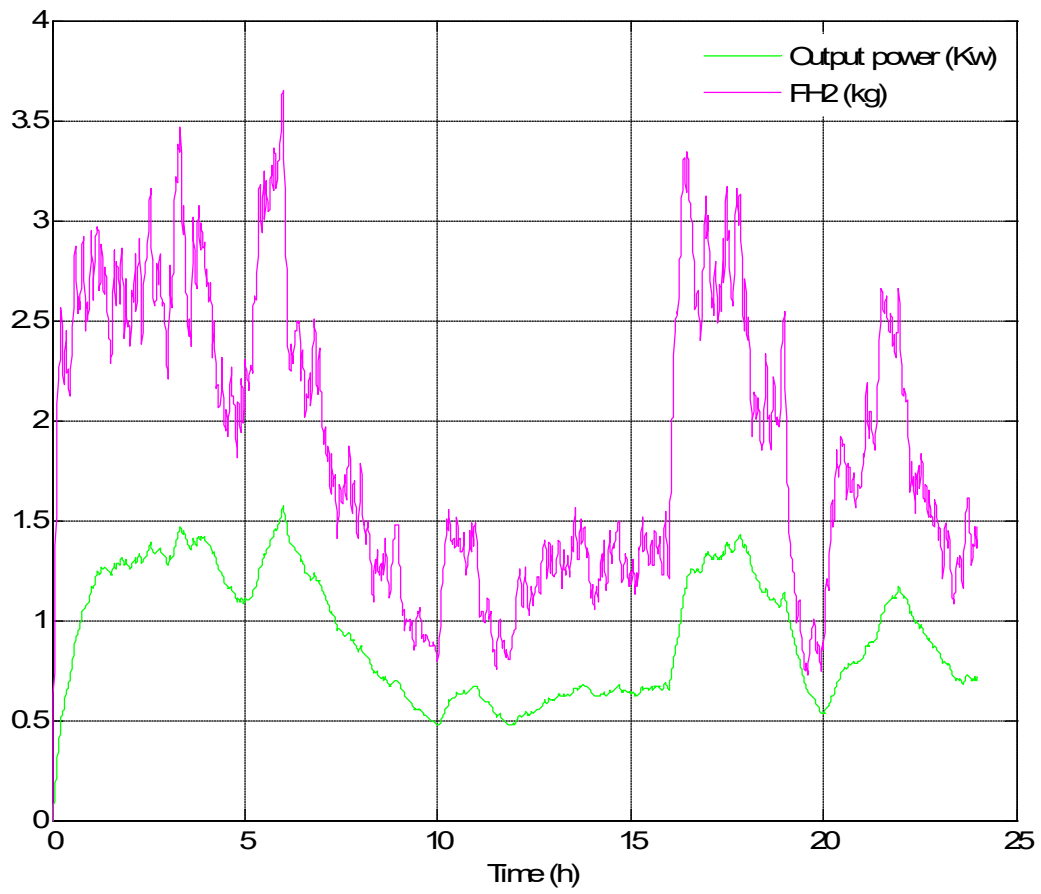

Figure 14. Hydrogen input \& Fuel cell output power

\subsection{Methanation reactor}

Methanation reactor generally operates with the Sabatier process which is based on the catalytic hydrogenation of carbon dioxide to methane. This process starts functioning at temperatures of $250^{\circ}$ to $400^{\circ} \mathrm{C}$ with pressures of $1 \mathrm{e} 80 \mathrm{bar}$, via nickel- and ruthenium-based catalysts [10]. A lot of mathematical models are existing in the literature, in order to see the input and output of this system a simple model based on calculating the speed of reaction has been used and it is expressed as follows[17]:

$$
w_{0}=K_{1} \cdot P_{H} \cdot P_{C O}\left(C_{1} \cdot P_{H}+P_{C O}+C_{2}\right)^{-1}
$$

With $P_{H}, P_{C O}$ are the partial pressures of the hydrogen and the carbon dioxide respectively.

The volume of the reactor can be calculated as follows:

$$
V_{s}=3.6 m_{c o}\left(w_{0} \cdot \rho_{C O} \cdot \rho_{N i} \cdot S A\right)^{-1}
$$




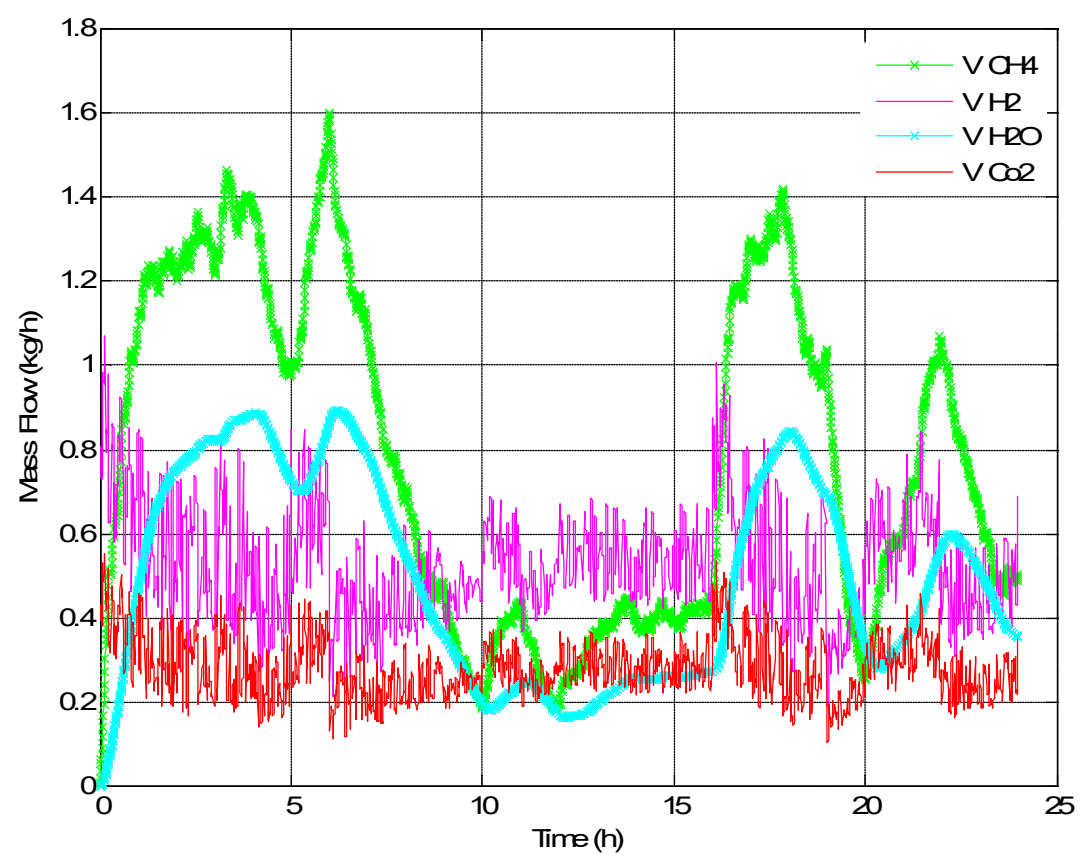

Figure 15. Mass flow evolution of methanation reactor

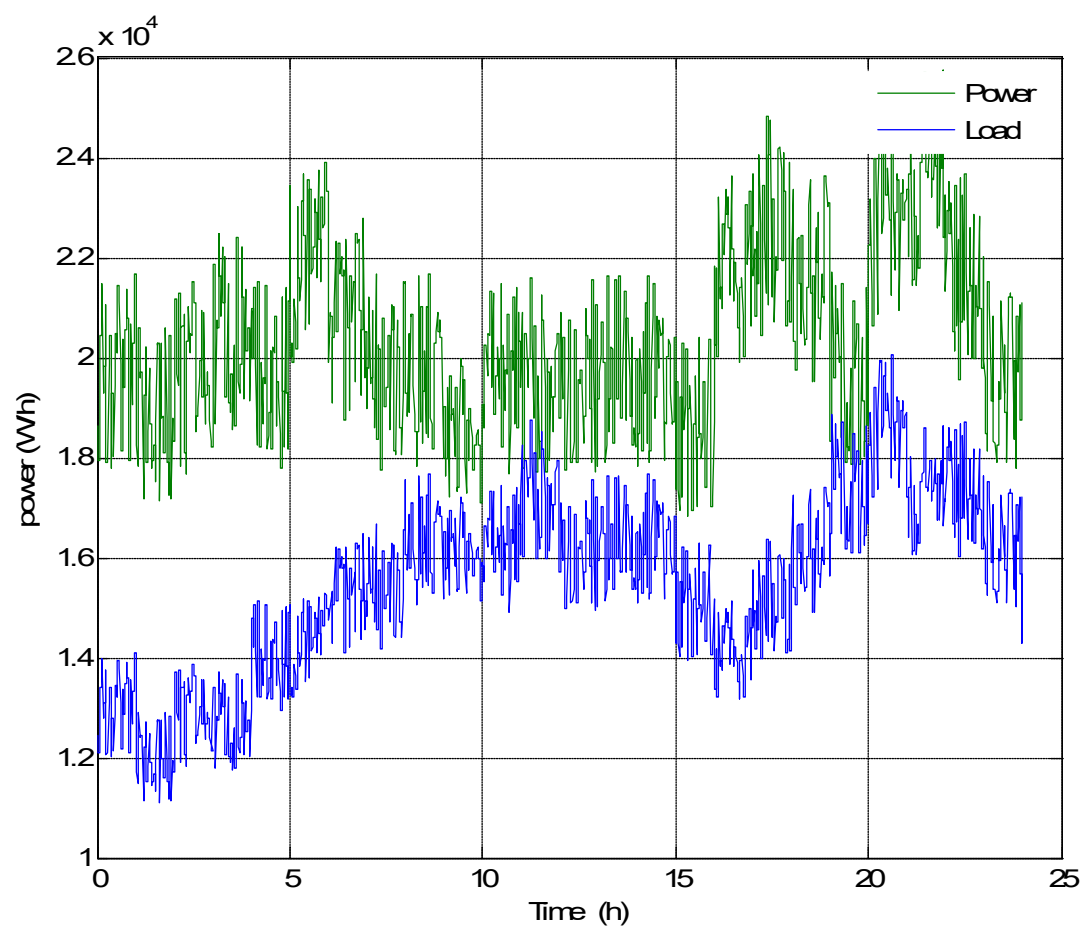

Figure 16. Variation of power production and load in the day

The Figure 16 shown the power production and load in the day and the Figure 15 represents the variation of input and output gases in the methanation reaction which is represented by Sabatier reaction where nickel catalyst is required to play the role of a regulator between the input hydrogen and the $\mathrm{CO}_{2}, \mathrm{CH}_{4}$ and $\mathrm{H}_{2} \mathrm{O}$ are the outlet gases of methanation reactor; there is an inverse 
relationship between inlet and outlet gases, the increase of $\mathrm{CH}_{4}$ flow is linked with $\mathrm{H}_{2} \mathrm{O}$ with 1.2 to the maximum of $1.6 \mathrm{Kg} / \mathrm{h}$ of Methane output and 0.6 to $0.8 \mathrm{Kg} / \mathrm{h}$ of water vapor between 00:00 to 9:00 and a decrease of Hydrogen and Carbone dioxide in this period. It is considered that this reaction starts running at 00:00, it can be see that it needs a time delay to reach the balance (about 1 hour) after this time the variation will depend on multiple variables such as electrical energy excess. Whereas $\mathrm{CO}_{2}$ and $\mathrm{H}_{2}$ temperature and pressure are not taken in consideration.

\section{Conclusion}

The modeling and simulation of the case studied in the first part has as main objective the study of the feasibility of both technology and the visualization of the various parameters at the operating curses. It has been observed that the implementation of a power to gas concept plays such an important role in the conservation and conversion of energy in particular in periods when the network presents peaks of overproduction. According to the results of the simulation represented in this paper the storage of energy as gases than for re-use is an optimal solution, which presents a good yield and it's achievable for the chosen location of the study and even for divers systems however the architecture of these systems become more complicated.

Methane production is a new solution allows more flexibility to hydrogen storage and utilization via the two ways studied. Methane production plays also an important role in the futures years with the improvement of methanation process. From an economic point of view and according to previsions represented in this paper appropriate system for the futures years should contain the both of systems PtH and PtM. The most important parameter to take in consideration is the fraction of hydrogen storage and this is due to the costs of storage and capacity storage. This fraction should varied from location to others according to primary sources of energy and $\mathrm{CO}_{2}$ sources.

Finally and due to this study a big challenge of Power to Gas Systems management should be developed to ensure a good level of efficiency.

\section{Acknowledgements}

This work was supported by MESOnexTeam/URMPE, UMBB University, Boumerdès, Algeria, Fuel cell Laboratory of the University of Technology Belfort Montbelillard, France withe the Applied Automation and Industrial Diagnostic Laboratory, University of Djelfa, Algeria.

\section{References}

1. Sebastian Schiebahn, Thomas Grube, Martin Robinius, Vanessa Tietze, Bhunesh Kumar, Detlef Stolten, Power to gas: Technological overview, systems analysis and economic assessment for a case study in Germany. International Journal of Hydrogen Energy, 2015, vol. 40, pp. 4285-4294.

2. Vandewalle J., Bruninx K., D'haeseleer W., Effects of large-scale power to gas conversion on the power, gas and carbon sectors and their interactions. Energy Conversion and Management, 2015, vol. 94, pp. 28-39.

3. Tabanjat A., M. Becherif, M. Emziane, D. Hissel, H. S. Ramadan, B. Mahmah, Fuzzy logic-based water heating control methodology for the efficiency enhancement of hybrid PV-PEM electrolyser systems. International Journal of Hydrogen Energy, 2015, vol. 40, no. 5, pp. 2149-2161.

4. Jonathan Lefebvre, Manuel Götz, Siegfried Bajohr, Rainer Reimert, Thomas Kolba, Improvement of three-phase methanation reactor performance for steady-state and transient operation. Fuel Processing Technology, 2015, vol. 132, pp. 83-90.

5. Ovidiu Mihai Balana, Mihaela-Ramona Bugaa, Aymeric Brunotb, Adrian Badeac, Daniel, Froelichd Technical and economic evaluation of Power-to-Gas in link with a $50 \mathrm{MW}$ wind park. Journal of Energy Storage, 2016, vol. 8, pp. 111-118.

6. Quan Zhuang, Philip Geddis, Allan Runstedtler, Bruce Clements, An integrated natural gas power cycle using hydrogen and carbon fuel cells. Fuel, 2017, vol. 209, pp. 76-84. 
7. Mehdi Baneshi, Farhad Hadianfard, Techno-economic feasibility of hybrid diesel / PV / wind / battery electricity generation systems for non-residential large electricity consumers under southern Iran climate conditions. Energy Conversion and Management, 2016, vol. 127, pp. 233-244.

8. Manuel Gotz, Jonathan Lefebvre, Friedemann Mors, Amy McDaniel Koch, Frank Graf, Siegfried Bajohr, Rainer Reimert, Thomas Kolb, Renewable Power-to-Gas: A technological and economic review. Renewable Energy, 2016, vol. 85, pp. 1371-1390.

9. Hossam A. Gabbar, Jason Runge, Daniel Bondarenko, Lowell Bower, Devarsh Pandya, Farayi Musharavati, Shaligram Pokharel, Performance evaluation of gas-power strategies for building energy conservation. Energy Conversion and Management, 2015, vol. 93, pp. 187-196.

10. Ahmed Boubenia, Ahmed Hafaifa, Abdellah Kouzou, Kamal Mohammedi, Mohamed Becherif, Carbone dioxide capture and utilization in gas turbine plants via the integration of power to gas. Petroleum, 2017, vol. 3, no. 1, pp. 127-137.

11. M. Becherif, H. S. Ramadan, K. Cabaret. Picard, Simoncini, O. Bethoux Hydrogen Energy Storage: New Techno-Economic Emergence Solution Analysis. Energy Procedia, 2015, vol. 74, pp. 371 - 380.

12. Rabi Ibrahim Rabady, Bayan Kenaan, Power spectral shaping for hydrogen production from silicon based hybrid thermo-photovoltaic water electrolysis. Energy, 2017, vol. 133, pp. 1-8.

13. Farivar Fazelpour, Nima Soltani, Marc A. Rosen, Economic analysis of standalone hybrid energy systems for application in Tehran, Iran. International Journal of Hydrogen Energy, 2016, vol. 41, no. 19, pp. 7732-7743.

14. Moksadur Rahman, Anders Malmquist, Modeling and Simulation of an Externally Fired Micro-Gas Turbine for Standalone Polygeneration Application, Journal of Engineering for Gas Turbines and Power, 2016, vol. 10. $1115-1.4033510$

15. Ekin Ozgirgin, Yllser Devrim, Ayhan Albostan, Modeling and simulation of a hybrid photovoltaic (PV) module-electrolyzer-PEM fuel cell system for micro-cogeneration applications. International Journal of Hydrogen Energy, 2015, vol. 40, no. 44, pp. 15336-15342.

16. Abolfazl Shiroudi, Seyed Reza Hosseini Taklimi, Seyed Ahmad Mousavifar, Peyman Taghipour, Stand-alone PV-hydrogen energy system in Taleghan-Iran using HOMER software: optimization and techno-economic analysis. Environment, Development and Sustainability, 2013, vol. 15, no. 5, pp. 1389-1402.

17. Hanna Er-rbib, Chakib Bouallou, Modeling and simulation of CO methanation process for renewable electricity storage. Energy, 2014, vol. 75, pp. 81-88.

18. Ashraf Balabel, Mohamed S. Zaky, Ismail Sakr, Optimum Operating Conditions for Alkaline Water Electrolysis Coupled with Solar PV Energy System. Arabian Journal for Science and Engineering, 2014, vol. 39, no. 5, pp. 4211-4220.

19. Akikur R.K., Saidur R. , Ullah K.R., Hajimolana S.A., Ping H.W., Hussain M.A., Economic feasibility analysis of a solar energy and solid oxide fuel cell-based cogeneration system in Malaysia. Clean Technologies and Environmental Policy, 2016, vol. 18, no. 3, pp. 669-687

20. Hatem Allagui, Dhia Mzoughi, Arafet Bouaicha, Adelkader Mami, Modeling and Simulation of $1.2 \mathrm{~kW}$ Nexa PEM Fuel Cell System. Indian Journal of Science and Technology, 2016, vol. 99, no. 9, pp. 1-8.

21. Bouchra Belaissaoui, Gilles Cabot, Marie-Sophie Cabot, David Willson, Eric Favre, An energetic analysis of CO 2 capture on a gas turbine combining flue gas recirculation and membrane separation. Energy, 2012, vol. 38, no.1, pp. 167-175.

22. Merkel, Tim C., et al., Power plant post-combustion carbon dioxide capture: an opportunity for membranes. Journal of membrane science, 2010, vol. 359, no. 1, pp. 126-139.

23. Gabriele Comodi, Massimiliano Renzi, Luca Cioccolanti, Flavio Caresana, Leonardo Pelagalli, Hybrid system with micro gas turbine and PV (photovoltaic) plant: Guidelines for sizing and management strategies. Energy 2015, vol. 89, pp. 226-235.

24. Hossein Nami, Ehsan Akrami, Analysis of a gas turbine based hybrid system by utilizing energy, exergy and exergoeconomic methodologies for steam, power and hydrogen production. Energy Conversion and Management, 2017, vol. 143, pp. 326-337.

25. Issam Abadlia, Mohamed Adjabi, Hamza Bouzeria, Sliding mode based power control of grid-connected photovoltaic-hydrogen hybrid system. International Journal of Hydrogen Energy, 2017, vol. 42, no. 47, pp. 28171-28182. 
26. Mojtaba Fereidooni, Ali Mostafaeipour, Vali Kalantar, Hossein Goudarzi, A comprehensive evaluation of hydrogen production from photovoltaic power station. Renewable and Sustainable Energy Reviews, 2018, vol. 82, Part 1, pp. 415-423.

27. Rochdi Bouchebbat, Sofiane Gherbi, A Novel Optimal Control and Management Strategy of Stand-Alone Hybrid PV/Wind/Diesel Power System. Journal of Control, Automation and Electrical Systems, 2017, vol. 28, no.2, pp. 284-296.

28. Tebibel H., Khellaf A., Menia S., Nouicer I., Design, modelling and optimal power and hydrogen management strategy of an off grid PV system for hydrogen production using methanol electrolysis. International Journal of Hydrogen Energy, 2017, vol. 42, no. 22, pp. 14950-14967.

\section{Appendix A}

Table 3. Simulation Parameter of Electrolyze

\begin{tabular}{|c|c|c|}
\hline Model & Paramet & Value \\
\hline \multicolumn{3}{|c|}{ er } \\
\hline \multirow[t]{8}{*}{ PEM Electrolyzer } & $n_{c s}$ & 150 \\
\hline & $E^{0}$ & $1.23 \mathrm{v}$ \\
\hline & $a_{\mathrm{H} 2 \mathrm{O}}$ & $\approx 1$ \\
\hline & $J_{0}$ & approximatively \\
\hline & & $2.74 \mathrm{KA} / \mathrm{m} 2$ \\
\hline & $a_{a c}$ & 0.16 \\
\hline & $a_{a a}$ & 0.23 \\
\hline & $j$ & $77.7 \mathrm{KA} / \mathrm{m} 2$ \\
\hline
\end{tabular}

Table 4. Simulation Parameter of Fuel Cell

\begin{tabular}{lcl}
\hline Model & Parameter & Value \\
\hline PEM Fuel cell & $n$ & 50 \\
& $T$ & $25^{\circ}$ \\
& $P_{H 2}^{*}$ & $1 \mathrm{~atm}$ \\
$P_{O 2}^{*}$ & $1 \mathrm{~atm}$ \\
$L C_{H 2}$ & $120,971 \mathrm{MJ} / \mathrm{Kg}$ \\
\hline
\end{tabular}

Table 5. Simulation Parameter of Methanation reactor

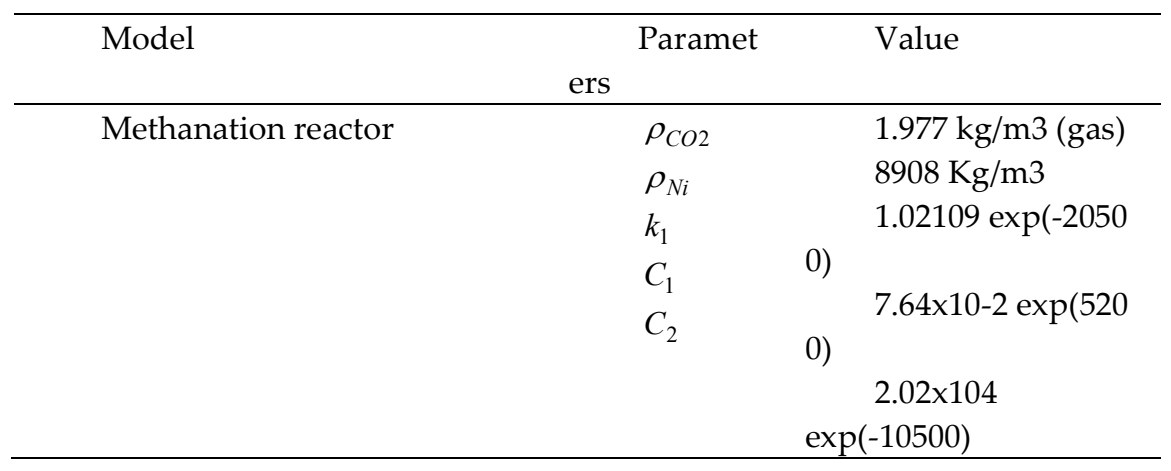

